\title{
THE COMMENTARY: A COUNTRY WITHERED
}

\author{
Jagjit S. Chadha*
}

Economic progress is a disruptive, dynamic force. Change is as pervasive as it is necessary. Crises not only can drive these changes but also reveal where change, or policy innovation, is most needed. Thus disruption has to be embraced as integral to the process of economic renewal and regeneration. And yet it is not an end in itself. Disruption for its own sake or without an adequate framework to catch the benefits for all of society is an empty populist goal. Whether it is from the Covid-19 pandemic or from Brexit, our economic and social structures must both flex in response to these shocks and must be sufficiently strong to survive. And the growing concern is that the very structures we currently have may cave in on themselves.

Britain is sadly not new to economic crises. Our postwar history can be written in terms of the responses to crises. Those of the 1970s were ultimately about the excessive power of labour in an era of poor structural reform and the financial crash of 2007-9 was about the excess power of financial capital. The subsequent period of economic doldrums has involved an uneasy truce between state, capital and labour but not one that has fostered much growing prosperity with a loss of much economic and political significance overseas. To which one can add the mounting threat to the continuing existence of the United Kingdom as a union of nations. The immediate prospects are grim. Either one of a pandemic or a break in trade relations would be bad enough but together they may be calamitous unless an appropriate policy intervention of some consequence is undertaken. Let me take them one at a time.

Brexit will imply an economy less oriented towards trade and most likely one with a lower level of productive capacity than would otherwise have been the case. Given the current structure of the economy, the transmission of this changed state is likely to involve a shallowing in capital employed in the economy, not only physically per worker, but also with a risk of some reduction in human and intangible capital formation and the development of a growing digital infrastructure gap between many of our regions and the global frontier. We can expect actual tariff and non-tariff barriers following Brexit to increase but also the uncertainty, which has become rampant, about the form and date of post-Brexit trade deals to persist. We can expect a Brexit to have most impact on the traded sector (both services and manufacturing) that has the strongest relations with the EU. But we can also expect any abrupt adoption of WTO trading rules to impart, at best, a further short, sharp shock to our recovery from the global pandemic.

The global public health crisis resulting from Covid-19 has led to lockdowns, involving constraints on labour mobility and restrictions on social interactions, with varying degrees of stringency here and abroad. As a consequence, economic activity in the first half of this year has contracted in an unparalleled manner. While there has been a recovery of some significance in the third quarter, it is precarious as there is an emerging second wave of virus infections and considerable uncertainty over the evolution of the pandemic. The impact of the lockdowns and social distancing has been particularly severely felt in the service sectors that have intensive social interactions: hospitality, recreation and tourism. These sectors are unlikely to recover to their pre-Covid levels until health risks abate.

\footnotetext{
*Director, NIESR. E-mail: j.chadha@niesr.ac.uk. These remarks reflect those made at the OECD's launch of its UK Economic Survey at NIESR on I4 October and also at the 2020 Annual Conference of the Society of Professional Economists on 2 Ist October.
}

(C) National Institute of Economic and Social Research, 2020.

DOI: $10.1017 /$ nie. 2020.42 
Domestic growth in the short run will be dominated both by the incidences of lockdown and the speed at which the social relations and health prospects return to normal. Normality will imply a running down of financial balances by households, the build-up of investment plans by firms and a reduction in public debt relative to national income. A sustained recovery in the rest of the world will help to support domestic growth but is likely to be hampered by a disorderly Brexit, as households and firms will face mixed signals about the direction of the economy and may face supply bottlenecks. Such an outcome will be particularly damaging in terms of rebuilding and reorienting the economy and the associated uncertainty may also act to limit the deployment and efficacy of policy interventions. The sectoral dimensions of these shocks may also spillover to amplify the initial shock. For example, the shock faced by the socially interactive service sector may be even more pronounced if trade with the rest of the world recedes. Equally, demand for many service sector outputs, such as design or IT, may go into a relative decline if elements of these globalised industries are diverted overseas. And as a very open economy, the UK is very sensitive to world economic growth, particularly from external economic contractions as well as the locational decisions of multinational firms.

While the economic impact from the Covid-19 pandemic is self-evident, the long-run effects of the prospective Brexit have been masked by year-to-year fluctuations in the economy. In principle, there are long-run effects from both. The latter leads to a compression and reorientation in trade and the former to a compression of certain service sector activities and a greater emphasis on health, education and the provision of a digital economy. Both involve a prevalence of forms of uncertainty for which the right response is fundamental reorganisation of economic policy institutions to place more emphasis on a long-term economic strategy that places restrictions on short-run tactical noise. Budgets and spending reviews can simply not be cancelled and policy needs to follow a substantially more measured and determined beat to rise to these extraordinary challenges. Brexit asks unanswered questions over the nature of our trading relations with the rest of the world and Covid-19 over the incidence of the infection through the population, the answers to which ought to determine economic policies. As well as the question over the space available for our standard policy instruments that ought to support these adjustments, the lack of forward-looking and comprehensive institutional frameworks for economic policy may deal a tragic blow to our economic prospects for a generation or more. 